\title{
Right lateral position can improving oxygen saturation and respiratory rate on under-five children with pneumonia
}

\author{
Novita Agustina, ${ }^{1}$ Nani Nurhaeni, ${ }^{2}$ Happy Hayati2 \\ 1 Faculty of Nursing; 'Department of Pediatric Nursing, Faculty of Nursing, Universitas Indonesia, Depok, Indonesia
}

\begin{abstract}
Pediatric patients with pneumonia experience respiratory distress in the form of shortness of breath and rapid breathing, which
\end{abstract}

Correspondence: Nani Nurhaeni, Department of Pediatric Nursing, Faculty of Nursing, Universitas Indonesia, Jalan Prof. Dr. Bahder Djohan, UI Campus, West Java, 16424, Depok, Indonesia.

Tel.: +62.21.78849120, Fax: +62.21.7864124.

E-mail: nani-n@ui.ac.id

Key words: Oxygen saturation; pneumonia; pronation position; respiratory rate; right lateral position; under-five children.

Acknowledgements: The present study is funded by Direktorat Riset dan Pengembangan Universitas Indonesia.

Contributions: NA, NN, and $\mathrm{HH}$ conceived the idea and plan of research. All authors discussed the results and reviewed the final manuscript.

Conflic of interests: The authors declare no conflict of interests.

Funding: This study is funded by the Direktorat Riset dan Pengembangan Universitas Indonesia under Hibah PUTI Saintekes scheme No: NKB-4608/UN2.RST/HKP.05.00/2020.

Conference presentation: This final manuscript has been presented at $7^{\text {th }}$ Virtual Biennial International Nursing Conference, Faculty of Nursing, Universitas Indonesia on September 24th, October 30th, November $16^{\text {th }} 2020$.

Availability of data and materials: All data generated or analyzed during this study are included in this published article.

Ethics approval and consent to participate: This study was approved by the Ethics Committee from Faculty of Nursing Universitas Indonesia (No: SK-43/UN2.F12.D1.2.1/ETIK.FIK.2020) and Muhammad Hoesin Central General Hospital and Faculty of Medicine Sriwijaya University (No: 047/kepkrsmhfkunsri/2020). All patients participating in this study signed a written informed consent form for participating in this study.

Consent for publication: Written informed consent was obtained from a legally authorized representative(s) for anonymized patient information to be published in this article.

Received for publication: 14 August 2020.

Accepted for publication: 9 April 2021.

This work is licensed under a Creative Commons Attribution NonCommercial 4.0 License (CC BY-NC 4.0).

๑Copyright: the Author(s), 2021

Licensee PAGEPress, Italy

La Pediatria Medica e Chirurgica 2021; 43(s1):262

doi:10.4081/pmc.2021.262 affects oxygen saturation. Oxygen saturation and respiratory rate can be increased by providing the right lateral position. Fulfillment of oxygen will affect the healing of children and can reduce the length of stay in hospital. The purpose of this study was to identify the effect of right lateral positioning on oxygen saturation and respiratory rate in under-five children with pneumonia. The study design was a quasi-experimental pre-posttest with control group design. Respondents were 32 infants with pneumonia, (right lateral=16 and control group=16), selected by consecutive sampling. Univariate and bivariate analyzes were performed. There was a significant difference in oxygen saturation before and after right lateral position ( $\mathrm{p}$-value $=0.000$ ) and there was a significant difference in the respiratory rate before and after right lateral position ( $p$-value $=0.000$ ). The results can be used to improve health services by promoting the right lateral position as a selftreatment intervention for increasing oxygen saturation and stabilizing respiratory rate in infants with pneumonia.

\section{Introduction}

According to the United Nations International Children's Fund (UNICEF) in 2016, pneumonia accounted for around $16 \%$ of the 5.6 million infant death cases in 2016. Indonesia's health profile data for 2017 stated that there were $46,34 \%$ with total 447.431 cases of infants with pneumonia. ${ }^{1}$ Pneumonia is a respiratory disease of the alveoli with frequently arising symptoms such as shortness of breath and rapid breathing, which is caused by viruses, fungi and bacteria. ${ }^{2}$ Pneumonia is classified as an acute disease usually caused by bacteria, with symptoms and signs of chest consolidation or a chest radiograph that has undergone new changes. ${ }^{3}$ Pneumonia is divided into three groups according to the Integrated Management of Childhood Illness (IMCI), namely: i) Severe pneumonia if the child shows symptoms such as cyanosis, severe respiratory distress such as grunting, severe chest retraction, severe general signs such as refusing to drink/suckle, lethargy and seizures; ii) Pneumonia if there are signs of rapid breathing, chest retraction and coughing; iii) Non-pneumonia if there are no signs or acute symptoms of pneumonia. 4

Pneumonia that is not treated properly can develop into hypoxemia and can affect the metabolic processes of body cells. ${ }^{5}$ Children with pneumonia who are hospitalized have often experience respiratory distress which is characterized by rapid breathing, chest retraction, nostril breathing and sometimes accompanied by additional breath sounds or stridor. 6 WHO recommends treatment of pneumonia which needs oxygen therapy if the Peripheral Capillary Oxygen Saturation (SpO2) value is less than or equal to $94 \%{ }^{7}$ Treatment of infant pneumonia includes giving oxygenation and nebulization also providing a comfortable position. ${ }^{5}$ A comfortable position reduces the coughing frequency and increases oxygen saturation so that the infants feel comfortable and can rest well. ${ }^{8}$ 
The lateral position is a position that maintains good patency of the airway. Research conducted by Jung, Kim, and Lee at the Dongsam Hospital Korea, suggests that the lateral position increases oxygen saturation and reduces the incidence of stridor and laryngospasm compared to the supine position for tracheal extubation in children. ${ }^{9}$ Previous study also state that patients with ventilators who are placed in a lateral position can avoid Ventilator-Associated Pneumonia (VAP) incidents. ${ }^{10}$ The results of a study in Townsville, Australia showed that the value of oxygen saturation when sleeping with a right-side position is higher than in the left position in cardio-respiration patients. ${ }^{11}$ Changes in lateral position will affect the blood's backflow to the heart so that the ability of the heart to pump will increase. Thus, the hemoglobin that binds oxygen increases and the oxygen in the cells will be fulfilled which then enable the oxygen saturation to increase. ${ }^{12}$ The recommended position is a right lateral position with an inclination of approximately 30 degrees to prevent compression of either lung. ${ }^{13}$ Adopting a lateral position aims to prevent the spine from being compressed, to facilitate breathing and to unencumber the body's organs. ${ }^{14}$

The pronation position has been widely studied and was found to have a positive effect on babies with heart problems. ${ }^{15}$ They concluded that in premature babies who use mechanical ventilation, pronation position intervention can be carried out because in this position, the pressure on the thoracic wall will decrease and promote increased lung expansion so that oxygenation status increases. Independent nursing intervention in the form of providing the right lateral position for infant with pneumonia is important. 5 Physiological position therapy such as lateral and prone positioning has a low level of risk. Furthermore, it does not require experienced therapists, and can be performed independently by patients with the help of parents. Positioning has not been the focus of nursing interventions, apart from collaborative interventions, research is therefore needed to assess the effect of right lateral position and pronation on oxygen saturation and respiratory rate in under-five pneumonia. The aim of the study was to identify the effect of the right lateral position on oxygen saturation and respiratory rate of infants with pneumonia

\section{Materials and Methods}

\section{Design}

This study used a quasi-experimental design with a preposttest control group. The intervention group would receive the right lateral position while the control group would receive the pronation position.

\section{Population/sample}

The participant in this study were all infants suffering from pneumonia who were encountered during data collection and were treated at a referral hospital in South Sumatra. The participants met the following inclusion criteria: i) Children aged less than 5 years with a diagnosis of pneumonia or broncho-pneumonia who are treated in hospital on day 1 or 2 ; ii) Infants with pneumonia who received 2 liters of nasal oxygen therapy and received the same antibiotics; and iii) Having no contraindications for intervention such as postoperative abdominal or thoracic wounds, spinal injuries, burns or fractures. The exclusion criteria for this study were children suffering from pneumonia who experienced worsening conditions and decreased awareness during research activities.

\section{Data collection}

The research sample was taken using consecutive sampling. The number of respondents was 32 pneumonia children under five years old, with 16 in each group. The research was conducted from March to July 2020. Data collection tools used were observation sheet for measurement of oxygen saturation and respiratory rate of children with pneumonia and questionnaires sheet contains demographic data and respondent characteristics, such as age, gender, nutritional status, and severity to obtain primary data directly from the respondents. The questionnaire was filled out by the researcher or research assistants. The researchers also used stationery (pen), pulse oximetry to assess oxygen saturation which had been calibrated by the hospital's electromedical technician, a pillow to support the head, a bow ruler to measure the tilt angle, a rolling pillow made with a 30 degree tilt angle, a guide sheet for position setting and a stop watch. The primary researcher was assisted by 2 research assistants and the inter-rater reliability test was conducted before data collection started.

\section{Data analysis}

Univariate analysis was used to analyse the characteristics of the research respondents including age, gender, nutritional status and disease severity that was processed using SPSS. The normality test was performed with the Shapiro-Wilk method and the results were normally distributed. The homogeneity test showed that the data was homogeneous which suggest that the samples from both groups came from the same population. The ethical principles applied were beneficence, respect for human dignity, respect for privacy and confidentiality and right to justice.

\section{Results}

The characteristics of respondents who participated in this study were as follows. The average age of children under five with pneumonia was 10.38 months; the proportion of boys and girls was the same which is $50 \%$; more boys were in the right lateral and more girls in the control group; nutritional status is mostly good nutritional status, (-2 SD to $2 \mathrm{SD}$ ); and the severity level according to WHO was pneumonia and severe pneumonia in this study, the majority of respondents were pneumonia $(84,4 \%)$.

Table 1 shows the results of the T-Dependent statistical test where the average oxygen saturation after right lateral position intervention increased compared to before the right lateral adjustment. In the control group, the average oxygen saturation after intervention increased although it was not statistically significant. The average respiratory rate after right lateral position intervention decreased. The average respiratory rate in the control group also decreased after the intervention period, although again it was not statistically significant. Table 2 shows the results of the TIndependent statistical test where there was a significant difference in the oxygen saturation and respiratory rate before and after giving right lateral position intervention. Whereas in the control group there was no difference in oxygen saturation and respiratory rate before and after being given the position.

The distinction between the two groups obtained from the Mann Whitney test showed that there was a significant difference in oxygen saturation and respiratory frequency in the intervention group and the control group. Analysis of the characteristic variables, (age, gender, nutritional status, and severity) on the post-test scores found no significant relation between respondent's characteristics regarding oxygen saturation and respiratory rate. 


\section{Discussion}

There was an increase in oxygen saturation after right lateral intervention of $4.625 \%$. The results of further analysis with the Dependent $\mathrm{T}$ test showed that there was a significant difference in oxygen saturation before, (pretest) and after, (posttest) right lateral position intervention. This demonstrates that there is a positive effect of using right lateral position intervention to increase oxygen saturation in children with pneumonia. This is in line with the research in Townsville, Australia, who showed that the oxygen saturation value during right side sleep was higher than in the left position in cardio-respiration patients. ${ }^{11}$

Changes in lateral position will affect the blood's backflow to the heart so that the ability of the heart to pump will increase. Thus, the hemoglobin that binds oxygen will also increase and oxygen in the cells will be fulfilled thereby increasing oxygen saturation. 12 Research by Yesni states that adopting a right lateral position for 30 minutes before bedtime in heart failure patients provides physical comfort, which indirectly increases oxygen saturation. 16 The results of further analysis with the Dependent T-test obtained a $\mathrm{p}$ value $=0.000<\alpha(0.05)$. It can therefore be concluded that there is a significant difference in breathing frequency before, (pretest) and after, (posttest) adopting the right lateral position intervention. This shows that there is a positive effect of using right lateral position intervention to decrease the respiratory rate of children with pneumonia. This is in line with the research conducted in Slovenia, which concluded that the right lateral position decreases the respiratory rate. ${ }^{17}$

According to Yesni, vagus activity when resting in the right lat- eral position will benefit the heart because the atrium position is anatomically on the right so that venous blood backflow decreases from the superior and inferior vena cava. ${ }^{16}$ The work of the heart will also be lighter and will increase activity in the parasympathetic nerves. Airway obstruction due to the tongue and palate being pushed back are also avoided. Researchers are of the opinion that the right lateral resting position will prevent obstruction of the airway in the pharyngeal area due to pushing the tongue and palate backward which can cause nasopharyngeal and oropharyngeal occlusion while the patient is sleeping, so that the patient will feel more comfortable when the right lateral position.

There was no difference in oxygen saturation before, (pretest) and after, (posttest) giving intervention to the control group. This shows that there is no effect of giving intervention in the control group on the increase in oxygen saturation in children with pneumonia. However, there was an increase in the average oxygen saturation of $1.31 \%$ compared to before adjustment in the control group although this result was not statistically significant. Most of the respondents experienced an increase in oxygen saturation.

There is no difference in the breathing frequency before, (pretest) and after, (posttest) administering intervention to the control group. This shows that there is no effect of adopting right lateral position intervention on decreasing respiratory frequency in children with pneumonia. In contrast to research by Anggraeni et $a l$, the pronation position is one of the recommended positions to be used as an intervention in increasing oxygen saturation and stabilizing respiratory rate. 18 Premature infants who require mechanical ventilation can use pronation position intervention, because in this position the pressure on the thoracic wall will decrease thereby increasing lung expansion so that oxygenation status increases.

Table 1. Overview of the before and after levels of oxygen saturation and respiratory rate of children with pneumonia in the right lateral position and control groups $(\mathbf{n}=32)$.

\begin{tabular}{lccccc} 
Measurement & \multicolumn{3}{c}{$\begin{array}{c}\text { Intervention Group } \\
\text { Right Lateral } \\
\text { Mean + SD Dev }\end{array}$} & $\begin{array}{c}\text { Control } \\
\text { Min-Max } \\
\text { Mean + SD Dev }\end{array}$ \\
$\begin{array}{c}\text { Oxygen Saturation } \\
\text { Before (Pretest) }\end{array}$ & $88-98$ & $93,88+3,649$ & $97-100$ & $95,13+3,160$ & 0,309 \\
After (Posttest) & $89-99$ & $98,50+0,894$ & $94-99$ & $96,44+1,504$ & 0,000 \\
Respiratory Rate & & & & & \\
Before (Pretest) & 55,19 & $55,19+6,911$ & $89-99$ & $57,00+6,314$ & 0,445 \\
After (Posttest) & 43,38 & $43,38+7,881$ & $94-99$ & $55,69+6,897$ & 0,000 \\
\hline
\end{tabular}

Table 2. Differences in the before and after levels of oxygen saturation and breathing frequency of children with pneumonia in the right lateral position (intervention) and pronation (control groups). $n=32$.

\begin{tabular}{|c|c|c|c|c|}
\hline & Mean & Standard Deviation & Average increase & P value \\
\hline \multicolumn{5}{|c|}{ Oxygen saturation } \\
\hline \multicolumn{5}{|c|}{ Right lateral } \\
\hline Before & 93.88 & 3.65 & 4.62 & 0.000 \\
\hline After & 98.50 & 0.89 & & \\
\hline \multicolumn{5}{|c|}{ Pronation (control) } \\
\hline Before & 95.13 & 3.16 & 1.31 & 0.064 \\
\hline After & 96.44 & 1.50 & & \\
\hline \multicolumn{5}{|c|}{ Respiratory rate } \\
\hline \multicolumn{5}{|c|}{ Right lateral } \\
\hline Before & 55.19 & 6.91 & -11.81 & 0.000 \\
\hline After & 43.38 & 7.88 & & \\
\hline \multicolumn{5}{|c|}{ Pronation (control) } \\
\hline Before & 57.00 & 6.31 & -1.31 & 0.170 \\
\hline After & 55.69 & 6.89 & & \\
\hline
\end{tabular}


The pronation position can also stabilize hemodynamics in premature infants. 15

There is a significant difference in oxygen saturation between the intervention and control groups and there is a significant differences in the respiratory rate between the intervention and control groups. The results of this study differ from those obtained by Punthmatharith and Mora, who found that oxygen saturation in the prone position is not significantly different from the supine position in infants. But in premature infants the value of oxygen saturation is higher in the prone position than in the lateral position. While the breathing frequency in the lateral position showed no significant difference from infants in the supine position. ${ }^{19}$

Gordon, Jones, Sealey, and Buettner in Townsville, Australia state that their results showed that the oxygen saturation value during right side sleep was higher than in the left position. ${ }^{11}$ Research by Tongyoo, Vilaichone, Ratanarat, and Permpikul conducted at Siriraj Hospital, Thailand stated that oxygen saturation increased in the right lateral position to $96 \%$ compared to left lateral in adolescent patients with ARDS. 20 The results of this study indicate that the right lateral position is more effective at increasing oxygen saturation than the pronation position. Giving a lateral position to children under five years in this study has a gradual impact, namely a change in oxygen saturation, which improve and is followed by a decrease in respiratory rate. The right lateral position can provide comfort so that the infant is calmer and circulation in the body becomes smooth.

The results of the Spearman Correlation test based on the posttest value showed that there was no significant difference between the age of infants with pneumonia and an increase in oxygen saturation. The results of this study are in line with research by Mawaddah et al., who found no significant relationship between age and oxygen saturation, $(\mathrm{p}=0.357)$ with a relationship coefficient of 0.158 which is classified as a very weak relation. The results of the Mann Whitney test showed that there was no relation between gender and disease severity with increased saturation in infants with pneumonia. ${ }^{21}$ Likewise, analysis of nutritional status using the Anova test, found no relation between increased oxygen saturation and nutritional status.

The results of this study were in line with Mawaddah et al., in that there was no significant relationship between nutritional status, oxygen saturation in children with pneumonia. ${ }^{21}$ The absence of a relationship between nutritional status and oxygen saturation and respiratory frequency in this study could have occurred because the majority of participants had a good nutritional status, thus causing the analysis results to be statistically insignificant. This study also showed no significant difference between the age of infants with pneumonia and a decrease in respiratory frequency. Gender characteristics and severity were analyzed which found no significant relationship between gender and severity and respiratory rate. Meanwhile, the nutritional status found no difference in the post test breathing frequency between well-nourished and malnourished infants.

\section{Limitation of the study}

The time for data collection was longer during the Covid-19 pandemic, repeated pronation positions when there was an interruption, the use of a rolling pillow with a tilt angle of $30 \square$ according to the child's age, pulse oximetry size in younger children.

\section{Implication of the study}

The results of this study can be a consideration for nurses to provide a right lateral position arrangement for pneumonia children by involving parents in its implementation according to the concept of family center care. This research will add to the library collection in nursing education, and add information or nursing science literature, and can become the basic data for further research.

\section{Conclusions}

There was a significant difference in oxygen saturation before, (pretest) and after, (posttest) right lateral position intervention (pvalue $=0.000$ ) and there was a significant difference in the respiratory rate before, (pretest) and after, (posttest) adopting right lateral position intervention, $(p$-value $=0.000)$. There was no difference in oxygen saturation before, (pretest) and after, (posttest) of intervention in the control group, ( $\mathrm{p}$-value $=0.064)$. In addition there was no difference in respiratory rate before, (pretest) and after, (posttest) administering intervention to the control group, $(\mathrm{p}$-value $=0.1701)$. There was a significant difference in oxygen saturation between the intervention of the right lateral position group and the control group, $(p$-value $=0.001)$. There was a significant difference in the respiratory frequency between the intervention group and the control group, $(\mathrm{p}$-value $=0,000)$.

\section{Recommendations}

The results of this study can be a consideration for nurses to provide a right lateral position arrangement for pneumonia children by involving parents in its implementation according to the concept of family center care. This research will add to the library collection in nursing education, and add information or nursing science literature, and can become the basic data for further research.

\section{References}

1. Wulandari RA. Pengaruh pemberian ASI eksklusif terhadap kejadian pneumonia balita di Jawa Timur. Jurnal Berkala Epidemiologi 2018;6:236-43.

2. Bartolf A, Cosgrove C. Pneumonia. Medicine (Baltimore) 2016;44:373-7.

3. Cukic V, Hadzic A. The most common detected bacteria in sputum of patients with community acquired pneumonia (CAP) treated in hospital. Med Arch 2016;70:354-8.

4. Soepardi J, Izwardy D, Priohutomo S, et al. Manajemen terpadu balita sakit (MTBS). Jakarta: Kementerian Kesehatan Republik Indonesia; 2015.

5. James SR, Nelson KA, Ashwill JW. Nursing care of children: principles and practice. 4th ed. St. Louis, MO: Elsevier; 2013. $851 \mathrm{p}$.

6. WHO. Revised WHO classification and treatment of childhood pneumonia at health facilities: evidence summaries. Switzerland: World Health Organization; 2014. 34 p.

7. Blanc J, Locatelli I, Rarau P, et al. Retrospective study on the usefulness of pulse oximetry for the identification of young children with severe illnesses and severe pneumonia in a rural outpatient clinic of Papua New Guinea. PLoS One 2019;4:e0213937.

8. Ling IT, Piccolo F, Mulrennan SA, Phillips MJ. Posture influences patient cough rate, sedative requirement and comfort during bronchoscopy: an observational cohort study. Cough 2011;7:9.

9. Jung H, Kim HJ, Lee YC. Comparison of lateral and supine 
positions for tracheal extubation in children: a randomized clinical trial. Anaesthesist 2019;68:303-8.

10. Bassi GL, Xiol EA, Pagliara F, et al. Body position and ventilator-associated pneumonia prevention. Semin Respir Crit Care Med 2017;38:371-80.

11. Gordon S, Jones A, Sealey R, Buettner P. Body position and cardio-respiratory variables in older people. Arch Gerontol Geriatr 2011;52:23-7.

12. Suyanti S, Iswari MF, Ginanjar MR. Pengaruh mobilisasi progresif level 1 terhadap tekanan darah dan saturasi oksigen pasien dengan penurunan kesadaran. Indonesian Journal for Health Sciences 2019;3:57-63.

13. Registered Nurses' Association of Ontario. Positioning techniques in long term care: self-directed learning package for health care providers. Toronto, Canada; 2007. 41 p.

14. Potter PA, Perry AG. Buku ajar fundamental keperawatan: konsep, proses, dan praktik. 4th ed. Jakarta: EGC; 2006.

15. Apriliawati A, Rosalina. The effect of prone position to oxygen saturations' level and respiratory rate among infants who being installed mechanical ventilation in NICU Koja Hospital. In: Rozi F, Soemanntri I, editors. The 2nd
International Multidisciplinary Conference 2016; Nov 15, 2016; Jakarta. Jakarta: Universitas Muhammadiyah Jakarta. pp. 541-6.

16. Yesni M. Pengaruh terapi posisi lateral kanan terhadap kkualitas tidur pasien gagal jantung di RSUP M Djamil Padang. Jurnal Akademika Baiturrahim Jambi 2019;8:117-25.

17. Kalisnik JM, Avbelj V, Trobec R, Gersak B. Position-dependent changes in vagal modulation after coronary artery bypass grafting. Comput Biol Med 2007;37:1404-8.

18. Anggraeni LD, Indiyah ES, Daryati S. Pengaruh posisi pronasi pada bayi prematur terhadap perubahan hemodinamik. Journal of Holistic Nursing Science 2019;6:9-14.

19. Punthmatharith B, Mora J. Effects of positioning on respiration rate, heart rate, and oxygen saturation in preterm infants: a crossover design. Pacific Rim Int J Nurs Res. 2018;22:187-99.

20. Tongyoo S, Vilaichone W, Ratanarat R, Permpikul C. The effect of lateral position on oxygenation in ARDS patients: a pilot study. J Med Assoc Thai 2006;89:S55-61.

21. Mawaddah E, Nurhaeni N, Wanda D. Do different positions affect the oxygen saturation and comfort level of children under five with pneumonia? Enferm Clin 2018;28:9-12. 